\title{
DEVELOPMENT OF GEL DOSAGE FORM OF ETHYL ACETATE EXTRACT OF MANGOSTEEN RIND (Garcinia mangostana L.)
}

\author{
Ketut Widyani Astuti ${ }^{1}$, Ni Putu Ayu Dewi Wijayanti ${ }^{1}$, I Gusti Ngurah Jemmy Anton Prasetia ${ }^{1}$, \\ Dewa Ayu Ferianta Sari ${ }^{1}$ \\ ${ }^{1}$ Department of Pharmacy, Faculty of Mathematics and Natural Sciences, Udayana University \\ ketutwidyani@gmail.com
}

\begin{abstract}
Alpha-mangostin is a xanthonoid compound contained in mangosteen rind (Garcinia mangostana L.) and has an antibacterial effect against Staphylococcus aureus, the bacterium that causes acne. In this study, mangosteen rind extract is formulated in a gel dosage form. This study aimed to determine the optimum formula, the physical and chemical properties as well as the optimum formula release profile of the gel dosage form of mangosteen rind extract.

The mangosteen rind extract gel formula consists of viscolam, propylene glycol, glycerin, microcare ${ }^{\circledR}$, ethyl acetate extract of mangosteen rind, and distilled water. The formula was optimized by varying the concentrations of viscolam (2\% and 5\%), propylene glycol (5\% and 20\%) and glycerin (2\% and 15\%) using a factorial experimental design program called Design Expert 7.0.0. The 8 formulas were developed into gel dosage form and the physical and chemical properties were then evaluated. The evaluation tests include viscosity, dispersive power, and $\mathrm{pH}$ tests. The evaluation results were processed using the Design Expert 7.0.0 program to determine the optimum formula.

The results of the analysis showed the optimum formula of gel dosage form of mangosteen rind extract with viscolam percentage of $4.97 \%$, propylene glycol of $9.91 \%$, glycerin of $12.23 \%$, microcare ${ }^{\circledR}$ of $0.3 \%$, TEA (q.s), ethyl acetate extract of mangosteen rind of $1 \%$, and distilled water of $45 \%$. The evaluation results of the physical and chemical properties of the gel optimum formula revealed the viscosity of $2,345 \mathrm{cps}$, dispersive power of $6.59 \mathrm{~cm}$, and $\mathrm{pH}$ of 6.74 . Alpha-mangostin release test on the optimum formula revealed a flux value of $41.327 \mu \mathrm{g} / \mathrm{cm}^{2} / \mathrm{t}^{1} /^{2}$. From these results, it is concluded that the optimum formula has met the physical and chemical characteristics of a good gel.
\end{abstract}

Keywords: alpha-mangostin, factorial experimental design, flux, gel

\section{INTRODUCTION}

Mangosteen (Garcinia mangostana L.) is one of the plants having antibacterial activity against acne-causing bacteria such as Staphylococcus aureus [1] as it contains $\alpha$ mangostin compounds in its rind [2]. The use of antibacterial activity on the dosage form used for the skin is more effective when made into a topical dosage form compared to the oral one because it can provide a local effect on the skin [3]. One of the dosage forms that can be used topically is a gel form. Gel dosage form has many advantages compared with other topical dosage forms as it contains water which makes it feel cold, cool, moist, easy to use, easily absorbed by the skin, thus providing a faster effect [4]. In addition, the high water content in the gel can reduce the risk of further inflammation due to the buildup of fat in the pores, where skin lipids can be fractionated by lipase produced by bacteria into free fatty acids. These fatty acids can cause tissue inflammation that is also one of the factors causing acne [5]. One type of gelling agents that can produce a good gel base is Sodium Polyacryloydimethyl
Taurate or better known as viscolam.

Based on the research conducted by Budiputra (2013), the use of viscolam at a concentration of 5\% resulted in a gel with stable viscosity and $\mathrm{pH}$ compared to HPMC, CMC Na, carboxymethyl chitosan and carbomer 940 [6]. In addition, the resulting gel has clear, soft, and a flowable characteristic which makes it easily poured. Viscolam as a gelling agent can be used in the concentration range from $0.3 \%$ to $5 \%$ [7].

Glycerin at a concentration of $5-15 \%$ serves as a cosolvent. The addition of glycerin at a certain concentration can increase the solubility of $\alpha$-mangostin in the water as a gel solvent and helps obtain gel with stable physical properties. The addition of cosolvent onto gel formula can also affect the physical properties of the dosage form. Based on the study by Sukmawati (2013), it is known that the increase of the glycerin concentration can raise the viscosity of the gel significantly [8].

Another major component in the preparation of the gel dosage form is humectants. The effect of the addition of 
humectants had been studied previously by Melani et al. (2005) and her research showed the viscosity of gel dosage form which tends to decrease with the increasing concentration of propylene glycol as a humectant [9]. Moreover, the addition of propylene glycol as a humectant at a concentration of $5-20 \%$ can affect the release of active substances from the gel base. This is because propylene glycol can absorb moisture from the environment and reduce evaporation of water from the dosage form. The water contained in the dosage form will serve as an absorption enhancer that can moisturize the skin, making it easier for the penetration of drug substances through the skin membrane to reach the area for its action [10], [11].

Based on the above background, it is necessary to conduct a study to optimize viscolam, glycerin and propylene glycol in the formula in order to obtain mangosteen rind extract gel with good physical and chemical characteristics. The optimum formula was determined by varying the concentrations of viscolam $(0.3$ $5 \%)$, glycerin $(2-15 \%)$ and propylene glycol (5-20\%), which were optimized using a factorial experimental design program, namely the Design Expert Version 7.0.0 program. Through the factorial experimental design, the optimum formula of the mangosteen rind extract gel can be determined based on the desirability value which is close to 1 , and the effect of each factor namely viscolam, propylene glycol and glycerin as well as the interaction of these three factors towards the response, namely the physical and chemical properties of the mangosteen rind extract gel simultaneously can be evaluated [12]. The release of the active substance, $\alpha$-mangostin of the optimum formula of the mangosteen rind extract gel obtained was then tested using Franz diffusion cell method, in order to obtain the release profile and the $\alpha$-mangostin flux value from the gel base.

\section{METHODS AND PROCEDURES}

\section{A, Optimization of Formula of Mangosteen Rind Extract Gel}

The formula of mangosteen rind extract gel to be used in this study consists of mangosteen rind extracts, microcare, and distilled water with various concentrations of viscolam, propylene glycol and glycerin. The dosage forms were prepared with a weight of 100 grams each. The formula is presented in Table 1.

\section{B. Preparation of Mangosteen Rind Extract Gel}

All the materials used in each formula were weighed based on the percentage in table 1 for 100 grams of gel that would be prepared. Viscolam was firstly expanded by dispersing it in distilled water and then it was stirred using a magnetic stirrer at $500 \mathrm{rpm}$ for 10 minutes. The Microcare ${ }^{\circledR}{ }^{\circledR}$ preservative was dissolved first into propylene glycol and glycerin, and then the mangosteen rind extract (mixture 1) was added to it. Mixture 1 was added to the viscolam that had been expanded, and then stirred at $500 \mathrm{rpm}$ for 5 minutes. For the next step, the $\mathrm{pH}$ of the gel dosage form was adjusted in the range of $\mathrm{pH}$ of 6.5-7 using TEA to obtain a clear and thick base, and then it was stirred again (at $500 \mathrm{rpm}$ for 5 minutes). Distilled water was then added to obtain a gel mass of 100 grams.

Table 1.

Gel Formula with Factorial Experimental Design

\begin{tabular}{|c|c|c|c|c|c|c|c|c|c|}
\hline $\begin{array}{l}\text { Name of } \\
\text { Material }\end{array}$ & Function & F1 & F2 & F3 & F4 & F5 & F6 & F7 & F8 \\
\hline Extract $(\% \mathrm{~b} / \mathrm{b})$ & $\begin{array}{l}\text { Active } \\
\text { substance }\end{array}$ & 0.5 & 0.5 & 0.5 & 0.5 & 0.5 & 0.5 & 0.5 & 0.5 \\
\hline $\begin{array}{l}\text { Propylene } \\
\text { glycol (\%b/b) }\end{array}$ & $\begin{array}{l}\text { Humec- } \\
\text { tant }\end{array}$ & 5.0 & 5.0 & 20.0 & 20.0 & 5.0 & 5.0 & 20.0 & 20.0 \\
\hline $\begin{array}{l}\text { Glycerin } \\
(\% \mathrm{~b} / \mathrm{b})\end{array}$ & Cosolvent & 2.0 & 2.0 & 2.0 & 2.0 & 15.0 & 15.0 & 15.0 & 15.0 \\
\hline $\begin{array}{l}\text { Viscolam }^{\circledR} \\
(\% \mathrm{~b} / \mathrm{b})\end{array}$ & $\begin{array}{l}\text { Gelling } \\
\text { agent }\end{array}$ & 2.0 & 5.0 & 2.0 & 5.0 & 2.0 & 5.0 & 2.0 & 5.0 \\
\hline TEA (\%b/b) & $\begin{array}{l}\text { Alkalizing } \\
\text { agent }\end{array}$ & qs & Qs & qs & qs & qs & qs & qs & qs \\
\hline $\begin{array}{l}\text { Microcare }{ }^{\circledR} \\
(\% \mathrm{~b} / \mathrm{b})\end{array}$ & $\begin{array}{l}\text { Preservati- } \\
\text { ve }\end{array}$ & 0.3 & 0.3 & 0.3 & 0.3 & 0.3 & 0.3 & 0.3 & 0.3 \\
\hline $\begin{array}{l}\text { Distilled water } \\
(\% \mathrm{~b} / \mathrm{b})\end{array}$ & Solvent & 100 & 100 & 100 & 100 & 100 & 100 & 100 & 100 \\
\hline
\end{tabular}

\section{Evaluation of Mangosteen Rind Extract Gel Physical Evaluation \\ a. Viscosity Test}

Viscosity measurement was carried out by placing a \pm 100 $\mathrm{mL}$ sample in a Brookfield DV-E viscometer until the spindle was submerged. The spindle size and speed of rotation used was set in advance to generate torque of 10$100 \%$. The Brookfield DV-E viscometer was run and then the viscosity of the dosage form of mangosteen rind extract gel could be read.

b. Dispersive Power Test

A total of 1 gram of the gel dosage form of mangosteen rind extract was placed on a glass plate measuring $20 \times 20 \mathrm{~cm}$, put on a sheet of graph paper. It was left for 60 seconds and then the diameter of the dosage form was measured. Then, it was covered with a piece of mica paper and given a load of 50 grams, 100 grams, and 125 grams respectively, and it was left for 60 seconds. The diameter of the dosage form was then measured. A good value of dispersive power of the gel dosage form is between $5 \mathrm{~cm}$ to $7 \mathrm{~cm}$ [13].

\section{Chemical Evaluation}

$\mathrm{pH}$ Test

A total of 1 gram of mangosteen rind extract gel was dissolved in $\mathrm{CO}_{2}$-free water to reach $10 \mathrm{~mL}$. A pH meter electrode was dipped into the solution being tested, and the $\mathrm{pH}$ meter needle was allowed to move until it indicated a settling position. The $\mathrm{pH}$ indicated by the $\mathrm{pH}$ meter needle was then recorded. A good $\mathrm{pH}$ of topical dosage form is in the range of 4 to 8 .

\section{Evaluation of Active Substance Release}

a. Preparation of Phosphate Buffer Solution of $0.01 \mathrm{M}$ and the $\mathrm{pH}$ of 6.0.

A solution of potassium phosphate monobasic of $0.2 \mathrm{M}$ was prepared by pouring 5.44 grams of potassium phosphate into a $200 \mathrm{ml}$ flask, and then some distilled water was added up to the defined limit. The $\mathrm{pH}$ was measured using a $\mathrm{pH}$ meter. If the $\mathrm{pH}$ meter has not shown a $\mathrm{pH}$ of $6.0, \mathrm{pH}$ adjustment is to be carried out by dripping a 
solution of $0.2 \mathrm{M} \mathrm{NaOH}$ slowly to the solution of potassium phosphate while observing the $\mathrm{pH}$ change.

b. Preparation of $\alpha$-mangostin Standard Solution

The $\alpha$-mangostin standard was dissolved in methanol to obtain the concentration of standard solution of $1 \mathrm{mg} / \mathrm{ml}$. The standard solution was then diluted with methanol to obtain a concentration of $50 \mathrm{ng} / \mu \mathrm{l}$ and $500 \mathrm{ng} / \mu \mathrm{l}$. A calibration curve was made with variations of $\alpha$-mangostin standard solution concentrations of $50 \mathrm{ng}, 100 \mathrm{ng}, 500 \mathrm{ng}$, $1,000 \mathrm{ng}, 1,500 \mathrm{ng}$ and 2,000 ng.

\section{c. Preparation of the Test Solution}

The test solution was prepared by dissolving 1 gram of gel with $10 \mathrm{ml}$ of phosphate buffer with a $\mathrm{pH}$ of 6.0 . Liquid-liquid extraction was then carried out to $2 \mathrm{ml}$ of gel solution by adding $2 \mathrm{ml}$ of chloroform. The mixture was then shaken and allowed to stand until it formed two layers. The chloroform phase was then taken as the test solution.

d. Release of Active Substances from the Gel Base

The release of $\alpha$-mangostin from the gel base of mangosteen rind extract was determined by Franz diffusion cell method which had been equipped with Whatman paper No. 1 that had been soaked in a solution of phosphate buffer having a $\mathrm{pH}$ of 6.0 for 30 minutes. The phosphate buffer solution with the $\mathrm{pH}$ of 6.0 was then put into the device up to the mark dividing the receptor compartment and the donor compartment. A magnetic stirrer was put into the receptor compartment as a stirrer. The Whatman paper was placed on the device and then fixed to ensure that there were no leaks. Then, 3 grams of gel were placed onto the testing device in the donor compartment. The magnetic stirrer was run at a speed of $250 \mathrm{rpm}$ and the temperature of the receptor compartment was kept at $32 \pm 1{ }^{\circ} \mathrm{C}$. As much as $2 \mathrm{ml}$ of sample was taken from the receptor compartment at every specific time, namely at the 15th, 30th, 45th, 60th, 75th, 90th, 105th, 120th, 180th, 240th, 300th, and 360th minute. In each taking of the said sample, the media content was replaced with the same volume. Liquid-liquid extraction was then carried out to the obtained samples by adding $2 \mathrm{ml}$ of chloroform, and the mixture was then shaken, and then allowed to stand until it formed two layers. The chloroform phase was taken, and then the level was determined using TLC-Spectrodensitometer.

e. Determination of $\alpha$-mangostin Level

The $\alpha$-mangostin was identified using TLCSpectrodensitometry, spot detection and spray reagents in the form of $\mathrm{H}_{2} \mathrm{SO}_{4} 10 \%$. An activated TLC plate of silica gel $60 \mathrm{~F}_{254}$ with a size of $20 \times 10 \mathrm{~cm}$ was then spotted with $\alpha$-mangostin standard solution with mass (ng/spot) variations of 50,100,500,1000,1500, 2000, $2500 \mathrm{ng} ; 10$ $\mu \mathrm{L}$ of test solution; and $10 \mu \mathrm{L}$ of sample using Linomat V. The mobile phase used for elution was a mixture of chloroform solvent: methanol (10:0.1) v/v. Elution was carried out with a distance of $8 \mathrm{~cm}$ from the starting point of the spot. Then, the next stage was performed in accordance with the general procedure of TLC. The separation of each spot was observed visually, under UV $254 \mathrm{~nm}$ and $366 \mathrm{~nm}$. The plate was then scanned using CAMAG TLC Scanner densitometer at a wavelength of 210 $\mathrm{nm}$ to observe the peak of the compound in the sample. It was then scanned at the wavelength range of $200-700 \mathrm{~nm}$ to see the maximum wavelength of the $\alpha$-mangostin. The value of $h R f$ and the spectrum of the $\alpha$-mangostin were observed. The plate was then re-identified by using spot detection and color reagents in the form of $\mathrm{H}_{2} \mathrm{SO}_{4} 10 \%$ which was then heated in an oven at $110^{\circ} \mathrm{C}$ for 10 minutes. The changes of colors on the plate were observed visually under $254 \mathrm{~nm}$ UV light and $366 \mathrm{~nm}$ UV light. The plate that had been sprayed was then rescanned with spectrophotodensitometer CAMAG TLC Scanner at the maximum wavelength of $\alpha$-mangostin and in the wavelength range of 200-700 $\mathrm{nm}$. The size of each standard compound was plotted with the concentration range of the spotted compound in order to obtain a calibration curve using regression equations. The concentration of the $\alpha$ mangostin in the sample was then calculated using the regression equation.

\section{E. Data Analysis}

The data obtained from the testing of physical and chemical properties of mangosteen rind extract gel include viscosity, dispersive power, and $\mathrm{pH}$. The optimum formula was determined using the factorial experimental design, namely Design Expert Version 7.0.0 program based on the desirability value closest to 1 . The desirability value closest to 1 indicates the higher suitability of the optimum optimization process with desired response variables. The output of this program is the effect of the concentration of each factor on the response determined, and the optimum formula can be determined

\section{RESULTS AND DISCUSSION}

The physical and chemical evaluation results in the form of viscosity, dispersive power, and $\mathrm{pH}$ of the 8 formulas can be seen in Table 2 .

Table 2.

Results of the physical and chemical evaluation of the formula

\begin{tabular}{cccc}
\hline Formula & Viscosity (cps) & $\begin{array}{c}\text { Dispersive } \\
\text { Power }(\mathbf{c m})\end{array}$ & $\mathbf{p H}$ \\
\hline 1 & 1,180 & 6.7 & 7.1 \\
2 & 3,832 & 6.0 & 8.18 \\
3 & 542 & 6.8 & 7.42 \\
4 & 602 & 5.1 & 7.77 \\
5 & 153.2 & 6.9 & 6.82 \\
6 & 2,212 & 6.7 & 6.65 \\
7 & 280.4 & 7.43 & 6.91 \\
8 & 1,174 & 6.3 & 6.74 \\
\hline
\end{tabular}

The optimum formula was then determined using the Design Expert 7.0.0 program. The evaluation carried out using the Design Expert 7.0.0 program showed that the optimum formula was a formula that contained viscolam of $4.97 \%$, propylene glycol of $9.91 \%$ and glycerin of $12.23 \%$. The physical and chemical properties of the optimum formula were then formulated and evaluated. The results of the evaluation of the physical and chemical properties of the optimum formula of the gel dosage form of mangosteen rind extract (Garcinia mangostana L.) in this study show 
the value of viscosity of $2,345 \mathrm{cps}$, the dispersive power of $6.59 \mathrm{~cm}$, and the dosage form $\mathrm{pH}$ of 6.74 . The evaluation of the physical and chemical properties reveals that the optimum formula has met the requirements of good dosage forms, namely having the viscosity value in the range of 2,000-4,000 cps, the dispersive power in the range of 5-7 $\mathrm{cm}$, and the $\mathrm{pH}$ of the dosage form in the range of 4-8. This optimum gel formula generated a lag time in the 30th minute when as much as $4.5 \mathrm{ng} / \mu \mathrm{l}$ was diffused with the flux value of $\alpha$-mangostin release of $41.327 \mu \mathrm{g} / \mathrm{cm}^{2} / \mathrm{t}^{1 / 2}$. The diffusion profile can be seen in Fig. 1.

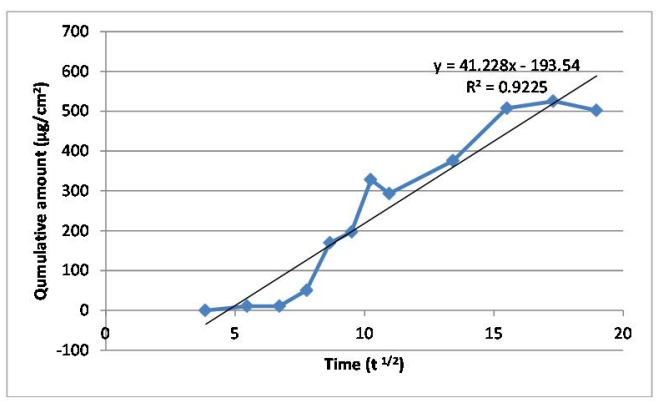

Fig. 1. Diffusion profile of the $\alpha$-mangostin in the gel dosage form with the optimum formula shows the amount of $\alpha$-mangostin diffused in 360 minutes

The optimum formula was determined by entering the data of the evaluation of physical and chemical properties of the dosage form into the factorial experimental design program, namely Design Expert Version 7.0.0 program. The optimum formula is determined based on the concentration of each factor that provides the desired response, namely the viscosity value in the range of 2,000-4,000 cps, the dispersive power value in the range of $5-7 \mathrm{~cm}$, and the $\mathrm{pH}$ of the dosage form in the range of 6-7.

The optimum formula of the mangosteen rind extract (Garcinia mangostana L.) gel obtained from the results of the analysis using the Design Expert 7.0.0 program is a formula that gives a desirability value of 1 which is a formula with the concentration of viscolam of $4.97 \%$, propylene glycol of $9.91 \%$ and glycerin of $12,23 \%$.

Optimization using the desirability function is one of the methods used to optimize the response process simultaneously. This method will make it possible to reach the process operating conditions that give the desired response value. The desirability function is a transformation of the response variables to a scale of 0 to 1 with the 0 desirability stating the unwanted response value or the response value is beyond the specification limits. Meanwhile, the 1 desirability states the ideal response value.

The optimum formula obtained from the analysis using Design expert 7.0.0. program was the formula containing the viscolam of $4.97 \%$, propylene glycol of $9.91 \%$, glycerin of $12.23 \%$, microcare $\circledR$ of $0.3 \%$, TEA (q.s), ethyl acetate extract of mangosteen rind of $1 \%$, and distilled water of $45 \%$. Then, the physical and chemical properties of the optimum formula were formulated and evaluated. The results of the evaluation of the physical and chemical properties of the optimum formula of the gel dosage form of mangosteen rind extract (Garcinia mangostana L.) from this study show the value of viscosity of $2,345 \mathrm{cps}$, dispersive power of $6.59 \mathrm{~cm}$, and dosage form $\mathrm{pH}$ of 6.74 . The results of the evaluation revealed that the physical and chemical evaluation of the optimum formula has met the requirements of good dosage forms, namely having the viscosity value in the range of 2,000-4,000 cps, the dispersive power value in the range of $5-7 \mathrm{~cm}$, and the $\mathrm{pH}$ of the dosage form in the range of 4-8. The release of this optimum formula was then tested to find out the profile and flux value of the release of $\alpha$-mangostin active substances from the gel base used.

The gel formula with a viscolam base of $4.97 \%$, propylene glycol of $9.91 \%$ and glycerin of $12.23 \%$ generated a lag time in the 30th minute when as much as $4.5 \mathrm{ng} / \mu \mathrm{l}$ was diffused with the flux value for the release of the $\alpha$-mangostin of $41.327 \mu \mathrm{g} / \mathrm{cm}^{2} / \mathrm{t}^{1} /^{2}$. Lag time is the time needed for the system to be in balance diffusion [10] marked by the start time of the detection of drug substance in the release media. The flux value obtained in the gel formulation with the optimum formula indicates a value greater than that in the previous study conducted by Budiari (2014), who formulated mangosteen rind extract gel with a HPMC base of $15 \%$, and propylene glycol of $15 \%$ resulting in the optimum release with the flux value of 8,5686 $\mu \mathrm{g} / \mathrm{cm}^{2} / \mathrm{t}^{1} /^{2}$. The higher flux value obtained in this study is due to the use of glycerin cosolvent in the formula that can also serve as a humectant, which affects the release of $\alpha$ mangostin from the gel base.

\section{CONCLUSION}

The optimum formula of mangosteen (Garcinia mangostana L.) rind extract gel has the composition of viscolam of $4.97 \%$, propylene glycol of $9.91 \%$, glycerin of $12.23 \%$, microcare ${ }^{\circledR}$ of $0.3 \%$, TEA (q.s), the ethyl acetate extract of mangosteen rind of $1 \%$, and distilled water of $45 \%$. The evaluation of the physical and chemical properties of the optimum dosage form of mangosteen rind extract gel shows a viscosity of $2,345 \mathrm{cps}$, dispersive power of $6.59 \mathrm{~cm}$, and the $\mathrm{pH}$ of the dosage form of 6.74 . From the release profile of the optimum formula, the flux value of the release of $\alpha$-mangostin obtained is $41.327 \mu \mathrm{g} / \mathrm{cm}^{2} / \mathrm{t}^{1} /^{2}$ and the lag time is in the 30th minute.

\section{ACKNOWLEDGEMENT}

We would like to express our sincere gratitude to the Directorate for Research and Community Services, Directorate General for Research and Development Strengthening, Ministry of Research, Technology and Higher Education for their support for this study.

\section{REFERENCES}

[1] Koh, J.J., et al., 2013. Rapid Bacterial Action of Alpha-Mangostin Againts MRSA As An Outcome of Membrane Targeting. Biochimica et Biophysica. pp. 834-844.

[2] Dachriyanus, R. Agustina and R. Andayani. 2014. Development and Validation of Thin-Layer Chromatographic Method for Determination of $\alpha$-mangostin in Young Pericarp, Ripe Pericarp and Bark Extract of Garcinia mangostana L. using TLC-Densitometry. J. Res. Pharm. Sci. 5(4): 294-298

[3] Draelos, Z.D. and L.A. Thaman. 2006. Cosmetic Formulation of Skin Care Product. New York: Taylor \& Francis Group. P. 377. 
[4] Ansel, H.C. 2008. Pengantar Bentuk Sediaan Farmasi Edisi 4. Translator: Farida Ibrahim. Jakarta: UI Press.

[5] Lieberman, H. A. 1997. Pharmaceutical Dosage Form: Disperse Sytems, Vol. 1. New York: Marcell Dekker Inc.

[6] Budiputra, D.K. 2013. "Pengembangan Formula dan Karakterisasi Nanoemulsi dan Nanosuspensi Kurkumin dalam Bentuk Gel untuk Rute Transdermal" (Master's thesis). Bogor: Institut Teknologi Bandung.

[7] Rita Corp. 2007. Viscolam AT 100EF. Material Safety Data Sheet. USA.

[8] Sukmawati, N.M.A. 2013. "Formulasi dan Evaluasi Sediaan Masker Wajah Gel Peel Off dari Ekstrak Etanol 96\% Kulit Buah Manggis (Garcinia mangostana L.)" (undergraduate thesis). Denpasar: Universitas Udayana

[9] Melani, H. D., T. Purwanti, and W. Soeratri. 2005. Korelasi Kadar Propilenglikol dalam Basis Dan Pelepasan Dietilammonium Diklofenak Dari Basis Gel Carbopol ETD 2020. Majalah Farmasi Airlangga, 5(1): 1-6.
[10] Martin, A., J. Swarbrick, and A. Cammarata. 1993. Farmasi Fisik: Dasar-dasar Farmasi Fisik dalam Ilmu Farmasetik. Third Edition. Translator: Yoshita. Jakarta: UI-Press. pp. 1124-1187.

[11] Berko, S., et al. 2014. Monitoring of Skin Penetration and Absorption with a New in Vivo Experimental Model. Farmacia, 62(6): 1157-1163.

[12] Dwiastuti, R. 2010. Pengaruh Penambahan CMC (Carboxymethyl Cellulose) sebagai Gelling Agent dan Propilen Glikol sebagai Humektan dalam Sediaan Gel Sunscreen Ekstrak Kering Polifenol Teh Hijau (Camellia sinensis L). Jurnal Penelitian. 13(2): 227-228.

[13] Garg, A., D. Aggarwal, S. Garg, and A.K. Sigla. 2002. Spreading of Semisolid Formulation. USA: Pharmaceutical Technology. pp. 84104. 